\title{
Dohányzásról anno és most
}

\section{[Smoking then and now]}

\author{
Szerző: Balogh Erika $\bowtie$ \\ Pécsi Tudományegyetem, Általános Orvostudományi Kar, Orvosi Népegészségtani Intézet
}

Beküldve: 2019. 12. 06.

doi: 10.24365/ef.v60i5.545

Kulcsszavak: dohányzás; halálozás; leszokás

Keywords: smoking; mortality; quitting

\begin{abstract}
„A dohányzás az Amerika felfedezése óta eltelt néhány évszázad alatt a civilizált országok egyik legkárosabb tömegszenvedélyévé vált. Az orvostudomány ma már bizonyítani tudja, hogy a dohányzás sokféle betegség és a korai elhalálozás veszélyét megsokszorozza. És mindezért az erős dohányos komoly anyagi áldozatot is vállal. Szerző sorraveszi, hogy mely betegségeknél van a nikotinnak kimutathatóan károsító szerepe. Ismerteti a dohányzásról való leszoktatás módjait, azok alkalmazásának szükségességét. A gyógyszeres kezelésnél (elvonásnál), a Lobelin alkalmazására mutat rá. Hangsúlyozza:
\end{abstract}

\begin{abstract}
legfontosabb a közvélemény megváltoztatása a dohányzás szenvedélyének elítélése érdekében" ${ }^{1}$ - olvashatjuk Wiltner Willibaldnak az Egészségügyi Felvilágosítás folyóiratban 54 évvel ezelótt megjelent, „Amit a dohányzásról tudnunk és mondanunk kell” címú írásában.
\end{abstract}

„A legkirívóbb kockázatot eddig a tüdőrák jelenti, mert napi 10 cigaretta 10-szeresre, 20 cigaretta 16-szorosára, 30 pedig 25-szörösére növeli a tüdőrák esélyét." ${ }^{1}$ A szerző táblázatban szemlélteti a dohányzás halálozási arányszámra gyakorolt hatását:

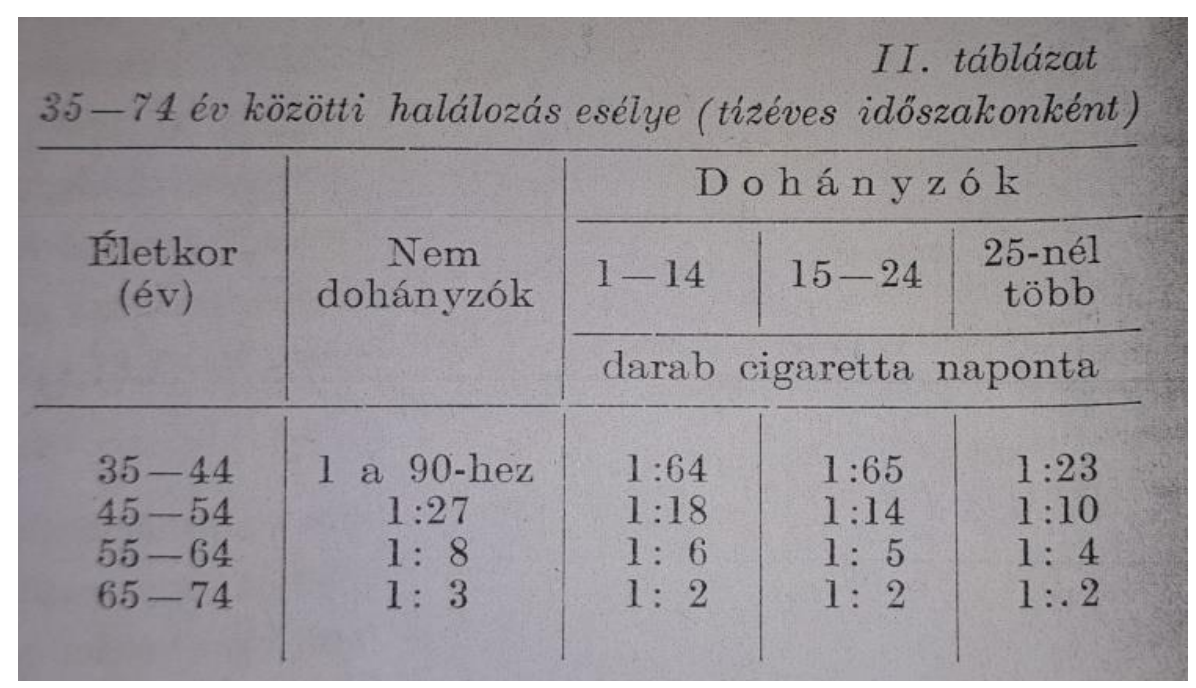

Forrás: Wiltner Willibald: Amit a dohányzásról tudnunk és mondanunk kell; Egészségügyi Felvilágosítás 1965. VI. évf. 145-150 
„Ha a fenti táblázatot szerencsejátékhoz kívánjuk hasonlítani: képzeljük el, hogy az első sor nem dohányzói egy olyan dobozból húzzák a vészes fekete golyót, amelyben még 90 fehér van. Ugyanilyen korú, de 25 cigarettát szívó dohányos dobozában 1 fekete golyóra csak 23 fehér esik, ennyivel nőtt meg a halálozásának eshetősége." ${ }^{1}$ Manapság a dohányzásnak tulajdonítható többlethalálozást hasonlóképpen számítják: a dohányzók nagyobb veszélyeztetettségét számszerúsítik a nem dohányzókéhoz képest (relatív kockázat). Annak az esélye például, hogy egy dohányos férfi tüdőrákban haljon meg, egy nem dohányzó társához képest több mint 21-szeres. ${ }^{2}$

Az összefoglaló közlemény 1965-ben, egy évvel azt követően jelent meg, hogy Terry Luther (az Amerikai Egyesült Államok tisztifőorvosa) bejelentette, hogy az addig összegyúlt adatok elemzése alapján a cigaretta használata komoly egészségügyi veszélyt jelent a fogyasztó számára: bizonyítottan ok-okozati összefüggésben áll a tüdőrák és a krónikus hörghurut kialakulásával, s más betegségek megjelenésében is fontos szerepet játszik. Mindez sokkolóan hatott, s megdöbbenést keltett az amerikai társadalomban, mert akkoriban a férfiak több mint fele (52\%-a), a nők harmada (34\%-a) cigarettázott. ${ }^{3}$ A bejelentés hatására az USA-ban széleskörü dohányzás ellenes kampány indult, melynek köszönhetően fokozatosan csökkent a cigaretta népszerüsége, s 2018-ra 14\%-ra mérséklődött a dohányzó felnőttek aránya. ${ }^{4}$

Nálunk sajnos Wiltner Willibald közleménye nem váltott ki ilyen drámai csökkenést, bár írásában már felhívta a figyelmet e káros szenvedély romboló hatására, s a dohányipar akkoriban újnak számító termékeivel, a füstszűrős cigarettákkal kapcsolatban is óva int: „Nikotin mentes dohány vagy filter alkalmazása a kockázatot és a károsodásokat nem csökkenti - a dohányosok illúziókba ringatására alkalmas. Minden amellett szól tehát, hogy aki nem dohányzik, ne szokjon hozzá, aki pedig dohányzik, szokjék le róla, hiszen a ma leggyakoribb betegségek keletkezésében ilyen fontos szerepe van." A leszokás kapcsán megfogalmazódik a jogos kérdés: „Hogyan lehet leszoktatni az ingadozókat? Nyilvánvaló, hogy a dohányzás szokásának mai társadalmi eltûrése mellett bármely tilalom - mint például kórházi tartózkodás, vonaton utazás idejére stb. - csak átmeneti hatású lehet." A leszokni vágyók számára gyógyszeres támogatás akkoriban nem állt rendelkezésre, bár a szerző beszámolt arról, hogy a világon és a saját gyakorlatában is Lobelint alkalmaztak a betegeknél. (A lobelin az indián dohánynövény alkaloidja, parciális nikotinerg-receptor agonista hatású, a dohányzásról való leszokás segítésére az 1930-as években kezdték alkalmazni. Hatásával kapcsolatban azonban nincs bizonyíték arra, hogy segíti a leszokást. ${ }^{5}$ ) Már ekkor felveti kérdésként, hogy elég-e csökkenteni a cigaretták számát vagy inkább teljesen abba kell hagyni a dohányzást?

Manapság a leszokástámogatás több formája is elérhető, szükség esetén gyógyszeres támogatás, nikotinpótló terápia és nikotinmentes készítmények is rendelkezésre állnak ${ }^{6}$. A végső cél a dohányzás teljes abbahagyásának elérése, a lehető legnagyobb egészségnyereség elérése érdekében.

1966-ban az Egészségügyi Felvilágosítás folyóiratban Székács Sándor „A cigaretta ártalmai” címú közleményével tovább folytatja az egészségügyi kockázatok ismertetését: „Legártalmasabb a cigarettázás, amely főleg ebben az évszázadban terjedt el és terjed továbbra is világszerte. 20-50 évi erős cigarettázás és a tüdőrák, valamint a szívkeringési betegségek gyakoribbá válása között kimutatható oki összefüggés van, amit a füst mélyreszívása folytán a dohánykátrány és a nikotin okoz. A gyermekek fejlődésére igen káros a dohányzás, a női szervezet is fokozottabban érzékeny a nikotin ártalmaira. Mindezt a szerző széles körű irodalmi utalásokkal és több összehasonlító adattal dokumentálja. Hangsúlyozza a nem dohányzók hathatósabb védelmének szükségességét. A dohányzás ártalmainak megelőzése terén nagy szerep hárul az egészségügyi felvilágosításra." ${ }^{7}$

Székely Lajos a fiatalkorúak dohányzására fókuszál 1966-ban megjelent cikkében: „Ifjúságunk körében mind nagyobb teret hódít a dohányzás... A nikotin különösen a fejlődő szervezetre fejt ki káros hatást...A fejlődésben levő idegrendszerre különösképpen káros hatású a nikotin, valamint a füsttel együtt a tüdőbe került égési termékek, szénszármazékok is." A szerző azzal a kérdéssel is részletesen foglalkozik, hogy miért dohányoznak a fiatalok, hiszen ennek ismerete elengedhetetlen az 
egészségügyi felvilágosítás során: „a szülőknek a fiatalkorú dohányzás kialakulására vonatkoztatott hatása csekély, igen jelentős a barátok befolyása, s számottevő az idősebb testvérek szerepe is" .

Vértes László élvezetes könyvismertetése, mely Marék Antal: „Dohányosok könyve” címü múvét mutatja be az Egészségügyi Felvilágosítás folyóirat olvasóinak 1970-ben, a dohányzás további, még manapság sem mindenki által ismert hatását villantja fel a neves francia író, Edmond de Goncourt mondásával: „A szerelem és a dohány antagonisták. Az utóbbi szeretete megöli az előbbire való vágyakozást" ${ }^{9}$

Szintén 1970-ben „A rák megelőzése és a korai rákszürés" címmel jelent meg A. Y. Tuyns, az Egészségügyi Világszervezet Nemzetközi Rákkutató Intézetének munkatársa (WHO IARC) által tartott előadás magyar fordítása. Ekkor a dohányzás kapcsán még csak a tüdőrák veszélyét említik, ma már tudjuk, hogy számos más daganat kialakulásában is szerepe van a dohányzásnak. ${ }^{10}$

Az Egészségügyi Felvilágosítás folyóirat 1970. évi utolsó számában Veres Pál a „Beszámolók, tapasztalatcsere" rovatban a dohányzással kapcsolatos Egészségügyi Fórumról (Fórum - a Magyar Televízió információ szolgálatának egyik legnépszerübb formájaként jellemezték) számolt be az olvasóknak.
Innen megismerhetjük a dohányzás elterjedését a hazai fiatalok körében: „A tizenkét éves tanulóknak 9,4 százaléka rendszeresen dohányzik, a tizennégy-tizenötéveseknek 13,5, a tizenhat-tizenhét évesek 27,14 százaléka dohányos. A tizennyolctizenkilenc éves korcsoportban 40 százalékon felüli a dohányzók aránya, ez a mutatószám az életkor növekedésével mind magasabb lesz." ${ }^{11}$ A fórumon "ellentétes nézetek csaptak össze, hogy vajon célravezető lenne-e az iskolákban megtiltani a dohányzást. A jelenlegi rendtartás a középiskolákban engedélyezi, de ezt - igen helyesen - nem mindenütt tartják magukra kötelezőnek és jó néhány iskolából számúzik a cigarettát. A dohányipar képviselője azt bizonyította, hogy a füstszűrős cigaretták a károsító anyagok jelentős részét visszatartják..."11

1971-ben, a második lapszámban a „Hírek, közlemények” rovatban „Előtérben a dohányzás elleni küzdelem" cím alatt is igen érdekes írásra bukkanhatunk, mely bepillantást enged a dohányzás elterjedésével kapcsolatos problémakörbe, s az azzal kapcsolatos megoldási javaslatokba: „Folyóiratunk számos közleményben foglalkozott a nikotinabúzus egészségkárosító hatásaival s talán nem túnik túlzásnak, ha azt mondjuk, hogy a dohányzás elleni küzdelem egyik fórumává vált. Legutóbb nemzetközi hírként közöltük a WHO végrehajtó bizottságának azt az egyhangú határozatát is, hogy ülései alatt a tagok nem dohányozhatnak." ${ }^{12}$

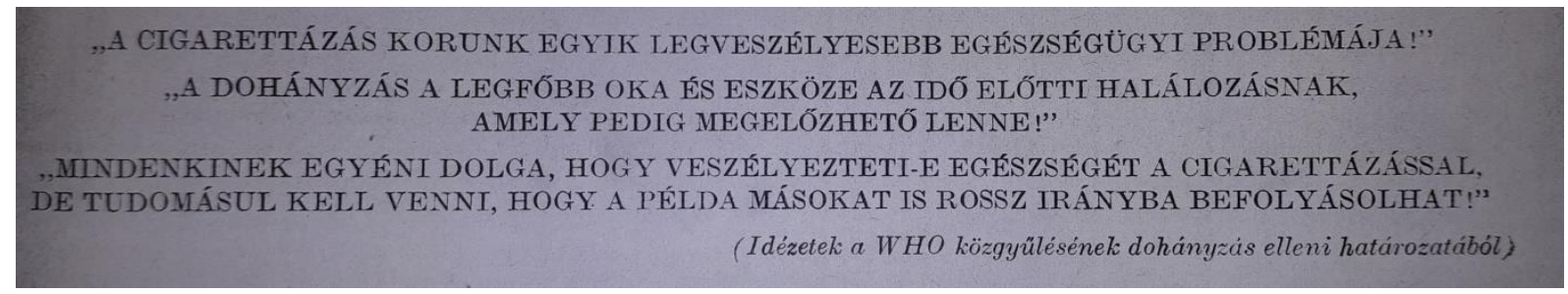

Forrás: Előtérben a dohányzás elleni küzdelem; Egészségügyi Felvilágosítás 1971. XII. évf. (2)77.

Az Egészségügyi Felvilágosítás folyóirat ugyanitt teljes terjedelmében közli Farádi László, az akkori egészségügyi miniszter első helyettesének felhívását a WHO alább részletezett határozatával kapcsolatban: „Az Egészségügyi Világszervezet 1970 májusában tartott közgyúlésén egyhangú határozatot hozott, melynek értelmében felszólította a tagállamokat, hogy tegyenek hatékony lépéseket a dohányzás ártalmainak csökkentése érdekében. Erre Magyarországon is megfogalmazódott, hogy az eddiginél szélesebb körben foglalkozzanak a különböző szervek (egészségügyi intézmények, és intézetek, általános és középiskolák, felsőoktatási intézmények, különböző társadalmi szervezetek, mindenekelőtt a Magyar Vöröskereszt és KISZ, a sajtó, a rádió és a televízió) az egészségneveléssel, 
ennek keretében a dohányzás ártalmaival kapcsolatos felvilágosító és nevelő munkával. E munka azt a célt tűzheti maga elé, hogy elsősorban a fiatalkorúak közül minél kevesebben váljanak dohányossá, annál is inkább, miután reprezentatív felmérések szerint hazánk e tekintetben az európai országok között - sajnálatos módon - „előkelő helyet” foglal el, amennyiben nálunk már a 12 éves életkorban elég jelentős, mintegy $10 \%$ a rendszeresen dohányzók száma, ezt követően az arány meredeken emelkedik. Hasonlóképpen el kell érni, hogy a zsúfolt helyiségekben (munkahelyek, üléstermek) ne dohányozzanak. A felvilágosító és nevelő munka elsődlegességének hangsúlyozása mellett azonban nem mellőzhetők bizonyos adminisztratív intézkedések sem. Ilyen intézkedésekre (a már meglevőkön kívül: városi közforgalmi eszközökön történő utazás során, színházakban, mozikban stb. tilos a dohányzás) az egészségügyi intézetekben és a középiskolákban van elsősorban szükség. A fentiek alapján kérem szíves intézkedését abban a tekintetben, hogy a felügyelete alatt múködő egészségügyi intézetek mindazon helyiségeiben, amelyek betegek vizsgálatára, gyógykezelésére, elhelyezésére, étkezésére szolgálnak ne csak a betegeknek, hanem az egészségügyi dolgozóknak is tiltsák meg a dohányzást. Rövid időn belül el kell érnünk, hogy az egészségügyi intézetek e tiltó rendszabály alapján követendő például szolgáljanak más főhatóságok által irányított intézmények számára.Budapest, 1970. november 24."13
E rövid szemezgetéssel a régi lapszámokból talán sikerült visszarepíteni az olvasót az időben, hogy a dohányzással kapcsolatos korabeli leírások, események alapján jobban megértsük, honnan is indultunk. A magyar lakosság körében bár lassan ugyan, de csökken a dohányzók aránya, azonban még mindig kétszer akkora, mint az Egyesült Államokban: 2014-ben a nők valamivel több, mint ötöde (22\%), a férfiak egyharmada (34\%) dohányzott. ${ }^{14}$ A dohányzás világszerte a leginkább megelőzhető haláloknak számít. Az Egészségügyi Világszervezet 2009-es becslése 5,4 millió ember haláláért tette felelőssé e káros szenvedélyt a világon, az akkori előrejelzés szerint 2030-ra 8 millióra nőhet ez a szám. ${ }^{15}$ Időközben azonban az előre jelzett értéket már most, 11 évvel korábban elértük, s már 2019-ben több mint 8 millióan vesztik életüket a dohányzás következtében fellépő betegségek miatt. ${ }^{16}$

Korunk újabb kihívása az alternatív nikotinos és dohánytermékek elterjedése, különösen a fiatalok körében. ${ }^{17}$ Ezek közül említést érdemel többek között az elektromos cigaretta, a vízipipa, valamint a dohány hevítésén alapuló készülékek (pl. IQOS) térnyerése. Az elkövetkezendő évek feladata, hogy ezen új, feltörekvő termékekkel kapcsolatban egyre növekvő számban megjelenő evidenciákat megismerjük és a lehetséges veszélyekről mind a lakosságot, mind pedig a döntéshozókat tájékoztassuk.

\section{HIVATKOZÁSOK}

\footnotetext{
${ }^{1}$ Wiltner W. Amit a dohányzásról tudnunk és mondanunk kell; Egészségügyi Felvilágosítás 1965. VI. évf. 145-150.

${ }^{2}$ A haláloki struktúra változása Magyarországon 2000-2012, KSH. 2014.

http://www.ksh.hu/docs/hun/xftp/idoszaki/pdf/halalokistruk.pdf (Elérve: 2019.12.04.)

${ }^{3}$ Cummings KM, Proctor RN. The changing public image of smoking in the United States: 1964-2014.

Cancer Epidemiol Biomarkers Prev. 2014;23(1):32-36. doi:10.1158/1055-9965.EPI-13-0798

${ }^{4}$ Creamer MR, Wang TW, Babb S, et al. Tobacco Product Use and Cessation Indicators Among Adults -

United States, 2018. MMWR Morb Mortal Wkly Rep 2019;68:1013-1019. doi:10.15585/mmwr.mm6845a2

${ }^{5}$ Stead LF, Hughes JR. Lobeline for smoking cessation. Cochrane Database of Systematic Reviews 2012, Issue 2. Art. No.: CD000124. doi: 10.1002/14651858.CD000124.pub2.

${ }^{6}$ Az Emberi Erőforrások Minisztériuma egészségügyi szakmai irányelve a dohányzásról való leszokás támogatásáról, 2019. EüK. 2. szám EMMI szakmai irányelv

7 Székács Sándor. A cigaretta ártalmai; Egészségügyi Felvilágosítás 1966. VII. évf. (3)122-125.

${ }^{8}$ Székely Lajos. A fiatalkorúak dohányzásáról; Egészségügyi Felvilágosítás 1966. VII. évf. (2)70-74.
} 
${ }^{9}$ Vértes László. Nicot orvostól a mai orvosig - könyvismertetés Marék Antal: Dohányosok könyve című múvéről; Egészségügyi Felvilágosítás 1970. XI. évf. 136-137.

10 Tuyns A. Y. A rák megelőzése és a korai rákszűrés; Egészségügyi Felvilágosítás 1970. XI. évf. 241-244.

${ }^{11}$ Veres Pál. Egészségügyi fórum a dohányzásról (Beszámoló); Egészségügyi Felvilágosítás 1970. XI. évf. 275-276.

12 Előtérben a dohányzás elleni küzdelem; Egészségügyi Felvilágosítás 1971. XII. évf. (2)77.

${ }^{13}$ Farádi L. Az egészségnevelés VI. országos értekezlete. Egészségügyi Felvilágosítás. 1971. XII. évf. (2)49.

${ }^{14}$ Központi Statisztikai Hivatal. A 2014-ben végrehajtott európai lakossági egészségfelmérés eredményei, Összefoglaló Adatok, 2018; http://www.ksh.hu/docs/hun/xftp/idoszaki/elef/elef2014_osszefoglalo.pdf

15 Tobacco, The problem, NMH Fact Sheet. World Health Organization. 2009

${ }^{16}$ Key facts, Tobacco World Health Organization. 2019 https://www.who.int/news-room/fact-sheets/detail/tobacco (Elérve: 2019.12.04.)

17 Torma A, Fazekas-Pongor V, Terebessy A, Pénzes M. Alternatív dohánytermékek használata fesztiválon részt vevő fiatal felnőttek körében; Egészségfejlesztés 2019 (60)4:5-18. doi:10.24365/ef.v60i4.463. 